\title{
Sustainable Use of Bioenergy Byproduct: Biochar for Nutrient Removal from Wastewater
}

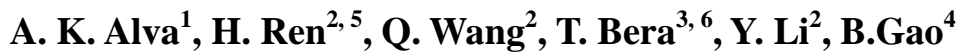 \\ ${ }^{1}$ Kuwait Institute for Scientific Research, Environmental and Life Sciences Research Centre, Kuwait \\ ${ }^{2}$ Department of Soil and Water Sciences, Tropical Research and Extension Center, IFAS, University of Florida, Homestead, FL \\ ${ }^{3}$ Indian Agricultural Research Institute, New Delhi, India \\ ${ }^{4}$ University of Florida, Agricultural and Biological Engineering Department, Gainesville, FL \\ ${ }^{5}$ Current Address: Witgang Far East Ltd., Beijing, China \\ ${ }^{6}$ Current Address: University of Florida, Horticultural Sciences Dept., Gainesville, FL
}

\begin{abstract}
Biochar, byproduct of pyrolysis for bioenergy production, is a good adsorbent of nutrients and pollutants from wastewater $(W W)$. Efficiency of nutrient removal by biochar is dependent on the feedstock used. Removal of nitrogen $(N)$ and phosphorus $(P)$ from WW was evaluated using a commercial biochar, from Dynamotive company (DY), activated carbon (AC), or biochars produced from peanut hull $(\mathrm{PH})$, bagasse $(\mathrm{BG})$ or hickory wood $(\mathrm{HW})$, at rates 2.5 to $100 \mathrm{~g} \mathrm{L^{-1 }}$ WW. Removal of NH4-N by DY and PH biochars increased significantly with an increase in biochar rate. In the case of $\mathrm{BG}$ and $\mathrm{HW}$ biochars, the highest removal of $\mathrm{NH}_{4}-\mathrm{N}$ was at $25 \mathrm{~g}$ $L^{-1}$ rate. Removal of $\mathrm{NH}_{4} \mathrm{~N}$ by $\mathrm{AC}$ was extremely low, except at $100 \mathrm{~g} \mathrm{~L}^{-1}$ rate. The Ortho-P adsorption from WW increased with increasing rates of biochar, except for $\mathrm{PH}$ biochar. This study demonstrated that most of the biochars, except PH biochar, are more effective than $\mathrm{AC}$ in removal of $\mathrm{NH}_{4} \mathrm{~N}$ and $\mathrm{P}$ from wastewater. The $\mathrm{N}$ and $\mathrm{P}$ enriched biochar can be used as soil amendment to agricultural soils to supply nutrients and enhance carbon sequestration.
\end{abstract}

Keywords: biochar, feedstock, pyrolysis, nutrient recycling, wastewater

\section{Introduction}

Industrial, agricultural or municipal wastewaters (WW) contain high concentrations of nutrients, metals, and other pollutants. Removal of these pollutants from $\mathrm{WW}$ is mandatory before the water can be discharged to streams/rivers or pumped to recharge groundwater (USEPA, 2000). Excess loading of nutrients from WW is a significant concern of negative effects on quality of surface water bodies (Smith et al., 1999). The cleanup process of WW is often expensive, but is required to minimize the potential loading of the pollutants to surface or groundwater resources. One of the alternatives is to explore cost effective adsorbent material for removing WW pollutants to make the waste water treatment cost effective (USEPA, 2000).

Biochar, a by-product of bioenergy production through pyrolysis of carbon-rich biomass feedstocks, has been suggested as a potential agent to clean the WW by adsorption of heavy metals and other pollutants, e.g. lead (Cao et al., 2009; Liu \& Zhang, 2009; Mohan et al., 2007), arsenic and cadmium (Mohan et al., 2007), naphthalene, 1naphthol (Chen \& Chen, 2009), atrazine (Cao et al., 2009), dye (Qiu et al., 2009), phosphorous (Mortula et al., 2007), copper and zinc (Wilson et al., 2003). The unique characteristics of biochar, i.e. small particle size, large surface area, and negative surface charge, make biochar a good adsorbent for positively charged ions (Liang et al., 2006; Lehmann, 2007). Biochar produced from different agricultural residues also contain calcium (Ca) and magnesium (Mg) carbonates (Yuan et al., 2011), which enable biochar to adsorb negatively charged ions including phosphate (Yao et al., 2011).

Variations in feedstock type and pyrolysis conditions may influence the resulting biochar's characteristics and hence its capacity to remove pollutants from WW (Cantrell et al., 2012; Novak et al., 2009; Singh et al., 2010). The objective of this study was to evaluate the adsorption of $\mathrm{N}$ and $\mathrm{P}$ from municipal WW by biochars produced from different feedstocks.

\section{Materials and Methods}

\section{Wastewater and Biochar}

Wastewater used in this study was sampled from a municipal wastewater treatment facility at the Tropical Research and Education Center (TREC), University of Florida (UF), Homestead, FL, and stored at 4o $\mathrm{C}$ prior to use. The WW was analyzed for the content of $\mathrm{NH}_{4}{ }^{+}-\mathrm{N}, \mathrm{NO}_{3}{ }^{-}-\mathrm{N}$, Ortho $\mathrm{P}$, $\mathrm{F}^{-}, \mathrm{Cl}^{-}, \mathrm{Br}^{-}$and $\mathrm{SO}_{4}{ }^{2-}$.

A commercially produced biochar (DY; DynamotiveEnergy Systems, Canada) and activated charcoal (AC; Fisher Scientific, Pittsburgh, PA) were compared with three additional biochars produced at the University of Florida, Gainesville, FL, by pyrolysis of Peanut Hull (PH), Bagasse (BG), and Hickory wood (HW) inside a furnace (Olympic $1823 \mathrm{HE}$ ) in $\mathrm{N} 2$ environment at $600{ }^{\circ} \mathrm{C}$ for $6 \mathrm{~h}, 300{ }^{\circ} \mathrm{C}$ for $24 \mathrm{~h}$, and $450{ }^{\circ} \mathrm{C}$ for $12 \mathrm{~h}$, respectively. One gram of each biochar or $\mathrm{AC}$ was extracted with distilled water in 1:40 ratio and concentrations of $\mathrm{NH}_{4}^{+}-\mathrm{N}, \mathrm{NO}_{3}{ }^{-}-\mathrm{N}$, Ortho $\mathrm{P}, \mathrm{F}^{-}, \mathrm{Cl}^{-}$, $\mathrm{Br}^{-}$and $\mathrm{SO}_{4}{ }^{2-}$ were analyzed

\section{Volume 6 Issue 1, January 2017




\section{International Journal of Science and Research (IJSR) \\ ISSN (Online): 2319-7064}

Index Copernicus Value (2015): 78.96 | Impact Factor (2015): 6.391

\section{Adsorption experiment}

The adsorption experiment was conducted by using $40 \mathrm{~mL}$ wastewater in $60 \mathrm{~mL}$ polypropylene tubes. Biochar or $\mathrm{AC}$ was added at $0.1,0.2,0.4,1.0,2.0$, or $4.0 \mathrm{~g}$ in 3 replications. These treatments resulted in 2.5, 5.0, 10.0, 25.0, 50.0, or $100.0 \mathrm{~g} \mathrm{~L}^{-1}$ rates. A treatment with no biochar was paralleledas a control. The suspensions were shaken at 100 rpm for $24 \mathrm{~h}$, filtered through Whatman No $42(90 \mathrm{~mm})$ filter paper for analysis of $\mathrm{NH}_{4}^{+}-\mathrm{N}, \mathrm{NO}_{3}^{-}-\mathrm{N}$ and Ortho-P using AQ2+ auto-analyzer (AQ-2 Discrete Automated Analyzer, Seal Analytical, Mequon, WI). An aliquot was re-filtered by nylon supported plain $0.45 \mu \mathrm{m}$ filter film $(25 \mathrm{~mm})$ for analysis of concentrations of $\mathrm{F}^{-}, \mathrm{Cl}^{-}, \mathrm{Br}^{-}$, and $\mathrm{SO}_{4}{ }^{2-}$ using a ion chromatograph (DIONEX AS 40-LC 20-EG 50-CP 25,Dionex, Sunnyvale, CA).

\section{Data Analysis}

The concentration of adsorbed ion on the sorbentwas calculated by

$$
q=\left[C_{i}-C_{e}\right] \times V / m
$$

$$
\text { Removal rate }(\%)=\left(C_{i}-C_{e}\right) / C_{i} \times 100
$$

Where,

$q(m g / k g)=$ the adsorption capacity of biochar or AC.

$C_{i}(m g / l)$ and $C_{e}(m g / l)=$ initial and equilibrium (after $24 \mathrm{~h}$ shaking) concentrations of $\mathrm{N}$ or $\mathrm{P}$ in wastewater, respectively.

$V(m l)=$ the volume of wastewater

$m(g)=$ the weight of biochar or AC in the tube (Variable per treatment)

Statistical significance of the treatments was evaluated by Analyses of Variance (ANOVA) test and mean separation between the treatments was analyzed by Duncan Multiple Range test.

\section{Results}

\section{$\mathrm{NH}_{4}{ }^{+}-\mathrm{N}$ removal}

The WW used in this study contained only $\mathrm{NH}_{4}{ }^{+}$form of $\mathrm{N}$ (Table 1). The rate of adsorption of $\mathrm{NH}_{4}-\mathrm{N}$ by the adsorbents peaked at $2.5 \mathrm{~g}$ absorbent $\mathrm{L}^{-1}$ of WW, except for $\mathrm{HW}$ biochar and $\mathrm{AC}$, and subsequently the adsorption rate decreased with further increase in rate of adsorbent (Fig. 1). For the HW biochar, the rate of NH4-N adsorption peaked at adsorbent rate of $5.0 \mathrm{~g} \mathrm{~L}^{-1} \mathrm{WW}$, remained constant at $10 \mathrm{~g} \mathrm{~L}^{-1}$ rate, and then declined.

For $\mathrm{AC}$, there was some $\mathrm{NH}_{4}-\mathrm{N}$ release at the first 3 rates of $\mathrm{AC}$ addition. With further increase in $\mathrm{AC}$ rates, there was slight adsorption of $\mathrm{NH}_{4}-\mathrm{N}$ far lower than that by the other biochar sources. At the highest rate of addition of adsorbent (100 $\mathrm{g} \mathrm{L}^{-1}$ of WW), the percent removal of $\mathrm{NH}_{4}-\mathrm{N}$ decreased in the order:

DY $(80 \%)>\mathrm{PH}(66 \%)>\mathrm{HW}(59 \%)>\mathrm{BG}(53 \%)>\mathrm{AC}$ (36\%) (Table 2).

The percent removal of $\mathrm{NH}_{4}-\mathrm{N}$ from WW increased with increasing rate of adsorbent addition to WW only for DY, $\mathrm{PH}$, and $\mathrm{AC}$ (Table 2). For HW and BG adsorbents, the percent removal of $\mathrm{NH}_{4}-\mathrm{N}$ peaked at $25.0 \mathrm{~g} \mathrm{~L}^{-1} \mathrm{WW}$, and declined with further increase in rate of adsorbent. At the $25.0 \mathrm{~g} \mathrm{~L}^{-1}$ rate, the percent removal of $\mathrm{NH} 4-\mathrm{N}$ ranked in the order: HW $(72 \%)>$ BG $(63 \%)>$ DY $(43 \%)>\mathrm{PH}(29 \%)>$ AC (4\%).

\section{Ortho- $P$ removal}

Ortho-P content of WW was $1.94 \mathrm{mg} \mathrm{L}^{-1}$ (Table 1). The Ortho-P concentration of $\mathrm{PH}$ biochar $4.7 \mathrm{mg} \mathrm{kg}$. Therefore, this biochar was not effective in Ortho-P removal from WW (Table 3). In fact, the data showed Ortho-P released from this biochar into the solution at all rates of $\mathrm{PH}$ biochar addition to WW. For the rest of the adsorbents the percent Ortho-P removal increased with increased rate of adsorbent addition. For HW and BG adsorbents the percent $P$ removal peaked at 96 and $98 \%$, respectively, with addition of $10.0 \mathrm{~g} \mathrm{~L}^{-1}$ rate. The percent Ortho-P removal slightly decreased with further increase in rate of biochar addition from 25.0 to $50.0 \mathrm{~g} \mathrm{~L}^{-1}$. For DY biochar the percent Ortho-P removal peaked $(87 \%)$ at $50.0 \mathrm{~g} \mathrm{~L}^{-1}$ rate with slight reduction $(79 \%)$ at $100.0 \mathrm{~g} \mathrm{~L}^{-1}$. The percent Ortho-P removal increased with each increment in AC addition up to $100 \mathrm{~g} \mathrm{~L}^{-}$ ${ }^{1}$. The DY, HW, and BG biochars were more effective in Ortho-P removal from WW as compared to that by AC. For the latter, the percent Ortho-P removal was $<7 \%$ with $\leq 10$ $\mathrm{g} \mathrm{L}^{-1}$, and then increased from 22 to $60 \%$ with an increase in rate from 25 to $100 \mathrm{~g} \mathrm{~L}^{-1}$. The most effective was $\mathrm{BG}$, which removed $98 \%$ of Ortho-P from WW with $5 \mathrm{~g} \mathrm{~L}^{-1}$. To remove $96 \%$ and $87 \%$ Ortho-P from WW, 100 and $50 \mathrm{~g}$ of HW and DY biochar were required, respectively.

The Ortho-P adsorption rate by the BG and HW biochar peaked at adsorbent rate of $2.5 \mathrm{~g} \mathrm{~L}^{-1} \mathrm{WW}$, and then declined with further increase in rate of adsorbent (Fig. 2). For the DY biochar, the rate of Ortho-P adsorption peaked at $10 \mathrm{~g} \mathrm{~L}^{-}$ ${ }^{1}$ and then decreased. The rate of Ortho-P adsorption by AC was much lower than that of BG, HW and DY biochar at 2.5, 5,10 , and $25 \mathrm{gL}^{-1}$ rates. This difference gradually decreased at 50 and $100 \mathrm{gL}-1$ rates.

\section{Discussion}

With increase in rate of addition of adsorbent the rate of $\mathrm{NH}_{4}-\mathrm{N}$ adsorption per unit weight of adsorbent decreased for most adsorbents. However, the percent removal of $\mathrm{NH}_{4}-\mathrm{N}$ from WW increased. This can be attributed to nonproportional increase in active adsorption sites with an increase in total weight of adsorbent or overlapping of active adsorption sites with an increase in weight of adsorbent in fixed volume of WW (Garg et al., 2007). Increase in total number of active adsorption sites accompanied by an increase in surface area appears to be the main factor contributing to an increase in percent $\mathrm{NH}_{4}-\mathrm{N}$ removal with an increase of adsorbent weight (Hussain et al., 2006). For $\mathrm{BG}$, the volume of biochar might also be a potential factor influencing the adsorption due to its "sponge characteristics". Excess rate of BG and HW may have caused insufficient contact with WW in the equilibration tube. This, in turn, contributed to decreased percent removal of NH4-N at $>25 \mathrm{~g} \mathrm{~L}^{-1}$ rates.

Among all the adsorbents used, BG biochar was most efficient for removing Ortho-P from WW by adsorption. Due

\section{Volume 6 Issue 1, January 2017




\section{International Journal of Science and Research (IJSR) \\ ISSN (Online): 2319-7064 \\ Index Copernicus Value (2015): 78.96 | Impact Factor (2015): 6.391}

to the high Ortho-P content of the $\mathrm{PH}$ biochar $(4.74 \mathrm{mg} \mathrm{kg}$ ${ }^{1}$ ), it was not a suitable adsorbent for removal of Ortho-P from WW. Instead, application of this biochar at all rates increased the Ortho-P content in the equilibration solution due to desorption of $\mathrm{P}$ from this biochar.

\section{References}

[1] Cantrell, K. B., Hunt, P. G., Uchimiya, M., Novak, J. M., Ro, K. S. 2012. Impact of pyrolysis temperature and manure source on physicochemical characteristics of biochar. Bioresource Technology 107:419-428.

[2] Cao, X., L. Ma, B. Gao, W. Harris, 2009. Dairy-manure derived biochar effectively sorbs lead and atrazine. Environmental Science and Technology 43:3285-3291.

[3] Chen, B., Z. Chen, 2009. Sorption of naphthalene and 1naphthol by biochars of orange peels with different pyrolytic temperatures. Chemosphere 76:127-133.

[4] Garg, U.K., Kaur, M.P., Garg, V.K., Sud, D., 2007 Removal of hexavalent chromium from aqueous solution by agricultural waste biomass. Hazardous Material 140:60-68.

[5] Hussain, S., Aziz, H.A., Isa, M.H., Adlan, M. N., Asaari, F.A.H., 2006. Physico-chemical method for ammonia removal from synthetic wastewater using limestone and GAC in batch and column studies. Bioresource Technology 98:874-880.

[6] Lehmann, J., 2007. Bio-energy in the black. Frontiers in Ecology and the Environment 5:381-387.

[7] Liang, B., Lehmann, J., Solomon, D., Kinyangi, J., Grossman,J., O’Neill, B., Skjemstad, J.O., Thies, J., Luizao, F.J., Petersen, J., Neves, E.G. 2006. Black carbon increases cation exchange capacity in soils. Soil Science Societyof America Journal 70:1719-1730.

[8] Liu, Z., and Zhang, F., 2009. Removal of lead from water using biochars prepared from hydrothermal liquefaction of biomass. Journal of Hazardous Material 167:933-939.

[9] Mohan, D., Pittman, C.U. Jr., Bricka, M., Smith, F., Yancey, B., Mohammad, J., Steele, P.H., AlexandreFranco, M.F., Gómez-Serrano, V., Gong. H., 2007. Sorption of arsenic, cadmium, and lead by chars produced from fast pyrolysis of wood and bark during bio-oil production. Journal of Colloid and Interface Science 310:57-73.

[10] Mortula, M., Gibbons, M., Gagnon, G., 2007. Phosphorus adsorption by naturally-occurring material and industrial by products. Journal of Environmental Engineering and Science 6:157-164.

[11] Novak, J.M., Lima, I., Baoshan, X., Gaskin, J.W., Steiner, C., Das, K.C., Watts, D.W., Busscher, W.J., Schomberg, H., 2009. Characterization of designer biochar produced at different temperatures and their effects on a loamy sand. Annals of Environmental Science 3:195-206.

[12] Qiu, Y., Zheng, Z., Zhou, Z., Sheng, G.D., 2009. Effectiveness and mechanisms of dye adsorption on a straw-based biochar. Bioresource Technology 100:5348-5351.

[13] Singh, B., Singh, B.P., Cowie, A.L. 2010. Characterization and evaluation of biochars for their application as soil amendment. Australian Journal of Soil Research 48:516-525.

[14] Smith, V.H., Tilman, G.D., Nekola, J.C., 1999. Eutrophication: impacts of excess nutrient inputs on freshwater, marine, and terrestrial ecosystems. Environmental Pollution 100:179-196.

[15] USEPA "Environmental Assessment for the Final Effluent Limitations Guidelines, Pretreatment Standards for New and Existing Sources and New Source Performance Standards for the Centralized Waste Treatment," Prepared by Charles Tamulonis (2000).

[16] Wilson, J.A., Pulford, I.D., Thomas, S., 2003. Sorption of $\mathrm{Cu}$ and $\mathrm{Zn}$ by bone charcoal. Environmental Geochemistry and Health 25:51-56.

[17] Yao, Y., Gao, B., Inyang, M., Zimmerman, A.R., Cao, X.D., Pullammanappallil, P., Yang, L.Y., 2011. Removal of phosphate from aqueous solution by biochar derived from anaerobically digested sugar beet tailings. Journal of Hazardous Material 190:501-507.

[18] Yuan, J. H., Xu, R. K., Zhang, H. 2011.The forms of alkalis in the biochar produced from crop residues at different temperatures. Bioresource Technology 102:3488-3497.

Table 1: Properties of different biochars, activated carbon, and wastewater

\begin{tabular}{|c|c|c|c|c|c|c|}
\hline & \multicolumn{4}{|c|}{ Biochar source / Feedstock } & \multirow{2}{*}{$\begin{array}{l}\text { Activated } \\
\text { Carbon }\end{array}$} & \multirow{2}{*}{ Wastewater } \\
\hline & Dynamotive & Hickory Wood & Peanut Hull & Bagasse & & \\
\hline $\begin{array}{c}\text { Pyrolysis } \\
\text { temperature }\left({ }^{\circ} \mathrm{C}\right)\end{array}$ & $400-450$ & 450 & 600 & 300 & - & - \\
\hline \multicolumn{7}{|c|}{$\leftarrow \mathrm{mg} \mathrm{kg}^{-1}$} \\
\hline $\mathrm{NH}_{4} \_\mathrm{N}$ & $0.28 \pm 0.04$ & $0.26 \pm 0.03$ & $0.18 \pm 0.02$ & $0.39 \pm 0.03$ & $1.02 \pm 0.54$ & $24.40 \pm 0.96$ \\
\hline $\mathrm{NO}_{3 \_} \mathrm{N}$ & $0.04 \pm 0.002$ & $0.02 \pm 0.02$ & $0.01 \pm 0.00$ & $0.06 \pm 0.02$ & $0.06 \pm 0.05$ & $0.00 \pm 0.00$ \\
\hline Ortho-P & $0.22 \pm 0.05$ & $0.12 \pm 0.02$ & $4.74 \pm 0.13$ & $0.08 \pm 0.01$ & $0.04 \pm 0.05$ & $1.94 \pm 0.07$ \\
\hline $\mathrm{F}^{-}$ & $1.22 \pm 0.43$ & $41.95 \pm 0.33$ & $0.09 \pm 0.02$ & $\mathrm{BD}$ & $0.54 \pm 0.30$ & $0.40 \pm 0.13$ \\
\hline $\mathrm{Cl}^{-}$ & $1.56 \pm 0.28$ & $22.71 \pm 2.62$ & $13.15 \pm 0.42$ & $3.61 \pm 0.42$ & $16.54 \pm 0.95$ & $147.21 \pm 3.15$ \\
\hline $\mathrm{Br}^{-}$ & $50.83 \pm 0.75$ & $\mathrm{BD}$ & $\mathrm{BD}$ & $\mathrm{BD}$ & $\mathrm{BD}$ & $27.15 \pm 0.58$ \\
\hline $\mathrm{SO}_{4}{ }^{2-}$ & $3.79 \pm 1.10$ & $10.90 \pm 0.08$ & $44.19 \pm 0.64$ & $25.04 \pm 0.35$ & $0.20 \pm 0.07$ & $2.56 \pm 0.96$ \\
\hline
\end{tabular}

$\mathrm{BD}=$ below detection limit

\section{Volume 6 Issue 1, January 2017 www.ijsr.net}




\section{International Journal of Science and Research (IJSR) \\ ISSN (Online): 2319-7064 \\ Index Copernicus Value (2015): 78.96 | Impact Factor (2015): 6.391}

Table 2: Percent removal of NH4-N from wastewater with addition of different rates of adsorbents

\begin{tabular}{|c|c|c|c|c|c|}
\hline Rate of adsorbent $\left(\mathrm{g} \mathrm{L}^{-1}\right)$ & Dynamotive (DY) & Hickory wood $(\mathrm{HW})$ & Peanuthull $(\mathrm{PH})$ & Bagasse $(\mathrm{BG})$ & Activatedcarbon $(\mathrm{AC})$ \\
\hline 2.5 & $10.4 \pm 1.6 \mathrm{e}$ & $7.1 \pm 1.2 \mathrm{e}$ & $3.9 \pm 0.8 \mathrm{e}$ & $12.5 \pm 2.0 \mathrm{f}$ & $-3.3 \pm 0.4 \mathrm{~d}$ \\
\hline 5.0 & $12.8 \pm 0.8 \mathrm{e}$ & $16.8 \pm 1.8 \mathrm{~d}$ & $4.9 \pm 1.0 \mathrm{e}$ & $23.1 \pm 0.7 \mathrm{e}$ & $-4.7 \pm 0.6 \mathrm{~d}$ \\
\hline 10.0 & $22.0 \pm 1.9 \mathrm{~d}$ & $33.6 \pm 1.0 \mathrm{c}$ & $14.5 \pm 2.8 \mathrm{~d}$ & $44.4 \pm 1.6 \mathrm{~d}$ & $-4.8 \pm 0.8 \mathrm{~d}$ \\
\hline 25.0 & $42.9 \pm 1.7 \mathrm{c}$ & $72.0 \pm 0.8 \mathrm{a}$ & $28.9 \pm 1.5 \mathrm{c}$ & $63.1 \pm 0.9 \mathrm{a}$ & $3.9 \pm 2.8 \mathrm{c}$ \\
\hline 50.0 & $64.0 \pm 1.5 \mathrm{~b}$ & $58.0 \pm 1.5 \mathrm{~b}$ & $44.9 \pm 3.2 \mathrm{~b}$ & $49.8 \pm 0.8 \mathrm{c}$ & $11.6 \pm 1.7 \mathrm{~b}$ \\
\hline 100.0 & $80.4 \pm 0.1 \mathrm{a}$ & $58.5 \pm 1.6 \mathrm{~b}$ & $65.7 \pm 3.7 \mathrm{a}$ & $53.8 \pm 1.2 \mathrm{~b}$ & $35.6 \pm 1.3 \mathrm{a}$ \\
\hline
\end{tabular}

Values after \pm symbol are the standard error for the respective treatment calculated from 3 replicates.

Means followed by different letters in each column are significantly different according to Duncan's new multiple range test at $\mathrm{P} \leqslant 0.05$

Table 3: Percent removal of Ortho-P from wastewater with addition of different rates of adsorbents

\begin{tabular}{|c|c|c|c|c|c|}
\hline Rate of adsorbent $\left(\mathrm{g} \mathrm{L}^{-1}\right)$ & $\begin{array}{c}\text { Dynamotive } \\
(\mathrm{DY})\end{array}$ & $\begin{array}{c}\text { Hickory wood } \\
(\mathrm{HW})\end{array}$ & $\begin{array}{c}\text { Peanut hull } \\
(\mathrm{PH})\end{array}$ & $\begin{array}{c}\text { Bagasse } \\
(\mathrm{BG})\end{array}$ & $\begin{array}{c}\text { Activated carbon } \\
(\mathrm{AC})\end{array}$ \\
\hline 2.5 & $7.5 \pm 0.7 \mathrm{e}$ & $46.2 \pm 2.4 \mathrm{c}$ & $-18.5 \pm 0.3$ & $78.1 \pm 1.7 \mathrm{~d}$ & $-0.6 \pm 0.4 \mathrm{e}$ \\
\hline 5.0 & $19.4 \pm 3.6 \mathrm{~d}$ & $71.9 \pm 0.3 \mathrm{~b}$ & $-31.3 \pm 0.8$ & $98.1 \pm 0.3 \mathrm{a}$ & $1.1 \pm 0.6 \mathrm{e}$ \\
\hline 10.0 & $45.9 \pm 2.1 \mathrm{c}$ & $95.6 \pm 0.3 \mathrm{a}$ & $-47.5 \pm 3.4$ & $98.1 \pm 0.9 \mathrm{a}$ & $6.8 \pm 1.0 \mathrm{~d}$ \\
\hline 25.0 & $79.0 \pm 2.0 \mathrm{~b}$ & $89.1 \pm 2.3 \mathrm{a}$ & $-42.8 \pm 2.9$ & $95.1 \pm 0.3 \mathrm{~b}$ & $22.0 \pm 1.1 \mathrm{c}$ \\
\hline 50.0 & $87.3 \pm 0.5 \mathrm{a}$ & $93.6 \pm 4.5 \mathrm{a}$ & $-42.8 \pm 8.4$ & $94.6 \pm 0.2 \mathrm{~b}$ & $41.9 \pm 1.4 \mathrm{~b}$ \\
\hline 100.0 & $78.7 \pm 0.4 \mathrm{~b}$ & $91.9 \pm 0.7 \mathrm{a}$ & $-96.4 \pm 4.8$ & $86.0 \pm 1.0 \mathrm{c}$ & $60.3 \pm 0.4 \mathrm{a}$ \\
\hline
\end{tabular}

Values after \pm symbol are the standard error for the respective treatment calculated from 3 replicates

Means followed by different letters in each column are significantly different according to Duncan's new multiple range test at $\mathrm{P} \leqslant 0.05$

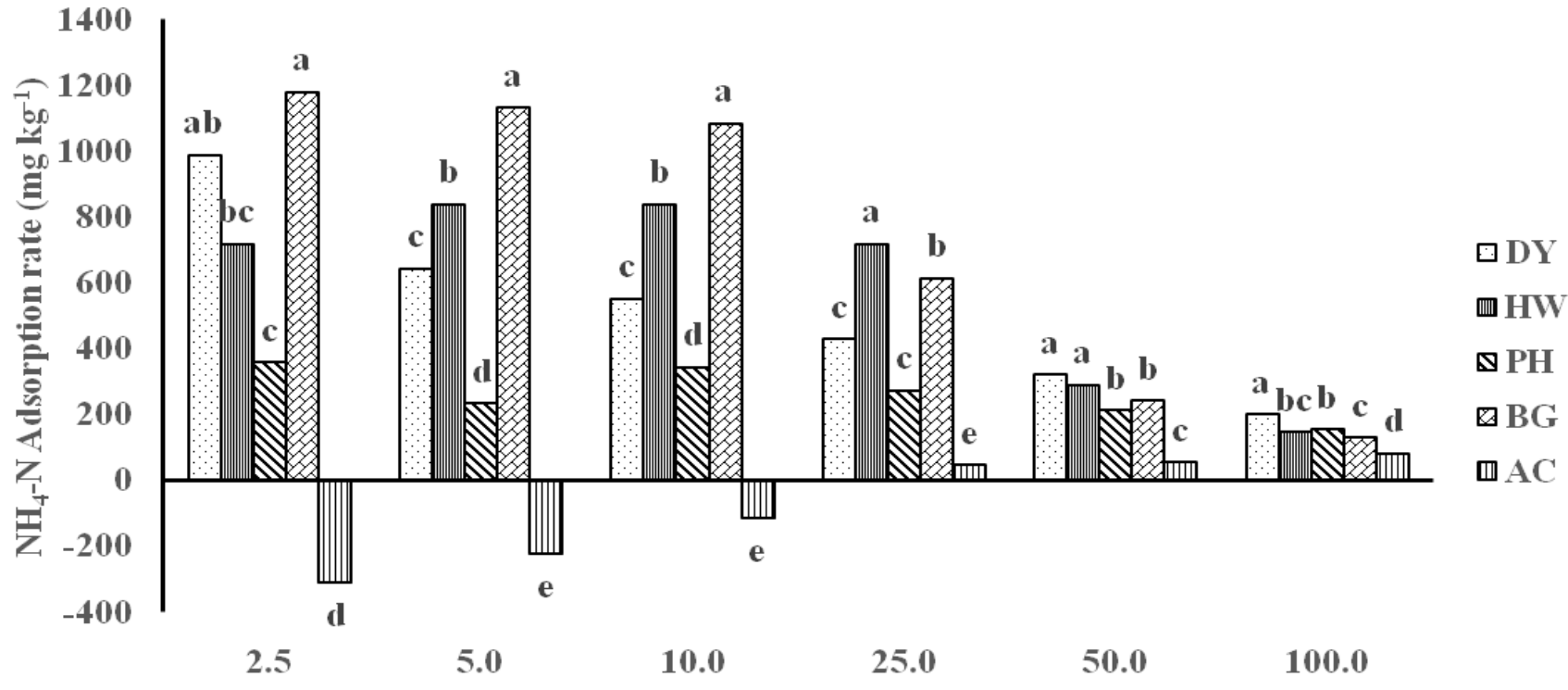

Adsorbent rate $\left(g \mathbf{L}^{-1}\right)$

Figure 1: $\mathrm{NH}_{+}-\mathrm{N}$ adsorption rates with application of different amounts of adsorbents to waste water.

Commercial biochars: DY = Dynamotive; $\mathrm{HW}=$ Hickory wood; $\mathrm{PH}=$ Peanut hull; $\mathrm{BG}=$ Bagasse

$\mathrm{AC}=$ Activated carbon. Means followed by different letters in each adsorbent rate are significantly different according to Duncan's new multiple range test at $\mathrm{P} \leqslant 0.05$.

Volume 6 Issue 1, January 2017 www.ijsr.net 


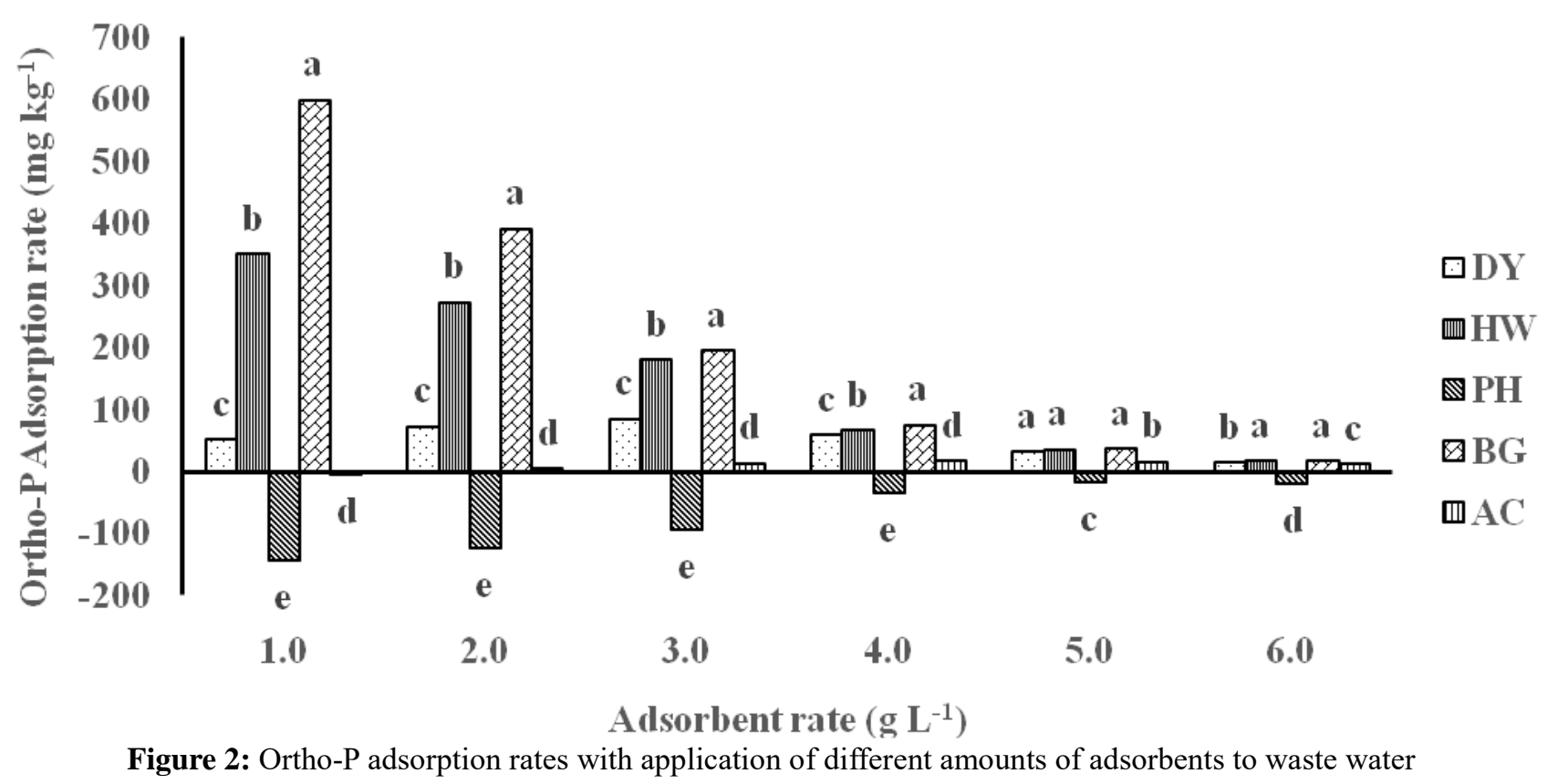

Commercial biochars: $\mathrm{DY}=$ Dynamotive HW $=$ Hickory wood PH $=$ Peanut hull; $\mathrm{BG}=$ Bagasse AC $=$ Activated carbon. Means followed by different letters in each adsorbent rate are significantly different according to Duncan's new multiple range test at $\mathrm{P} \leqslant 0.05$. 